\title{
Front Matter: Volume 11543
}

, "Front Matter: Volume 11543," Proc. SPIE 11543, Artificial Intelligence and Machine Learning in Defense Applications II, 1154301 (13 October 2020); doi: $10.1117 / 12.2584651$

SPIE. Event: SPIE Security + Defence, 2020, Online Only 


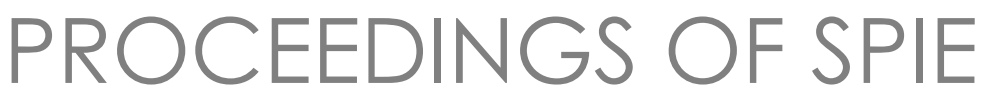

\section{Artificial Intelligence and Machine Learning in Defense Applications II}

Judith Dijk

Editor

21-25 September 2020

Online Only, United Kingdom

Sponsored by

SPIE

Cooperating Organisations

European Optical Society

Cranfield University (United Kingdom)

Technology Scotland (United Kingdom)

Visit Scotland (United Kingdom)

CENSIS (United Kingdom)

Published by

SPIE

Volume 11543 
The papers in this volume were part of the technical conference cited on the cover and title page. Papers were selected and subject to review by the editors and conference program committee. Some conference presentations may not be available for publication. Additional papers and presentation recordings may be available online in the SPIE Digital Library at SPIEDigitalLibrary.org.

The papers reflect the work and thoughts of the authors and are published herein as submitted. The publisher is not responsible for the validity of the information or for any outcomes resulting from reliance thereon.

Please use the following format to cite material from these proceedings:

Author(s), "Title of Paper," in Artificial Intelligence and Machine Learning in Defense Applications II, edited by Judith Dijk, Proceedings of SPIE Vol. 11543 (SPIE, Bellingham, WA, 2020) Seven-digit Article CID Number.

ISSN: 0277-786X

ISSN: 1996-756X (electronic)

ISBN: 9781510638990

ISBN: 9781510639003 (electronic)

Published by

SPIE

P.O. Box 10, Bellingham, Washington 98227-0010 USA

Telephone +1 3606763290 (Pacific Time) · Fax +1 3606471445

SPIE.org

Copyright (c) 2020, Society of Photo-Optical Instrumentation Engineers.

Copying of material in this book for internal or personal use, or for the internal or personal use of specific clients, beyond the fair use provisions granted by the U.S. Copyright Law is authorized by SPIE subject to payment of copying fees. The Transactional Reporting Service base fee for this volume is $\$ 21.00$ per article (or portion thereof), which should be paid directly to the Copyright Clearance Center (CCC), 222 Rosewood Drive, Danvers, MA 01923. Payment may also be made electronically through CCC Online at copyright.com. Other copying for republication, resale, advertising or promotion, or any form of systematic or multiple reproduction of any material in this book is prohibited except with permission in writing from the publisher. The CCC fee code is $0277-$ $786 \mathrm{X} / 20 / \$ 21.00$.

Printed in the United States of America by Curran Associates, Inc., under license from SPIE.

Publication of record for individual papers is online in the SPIE Digital Library.

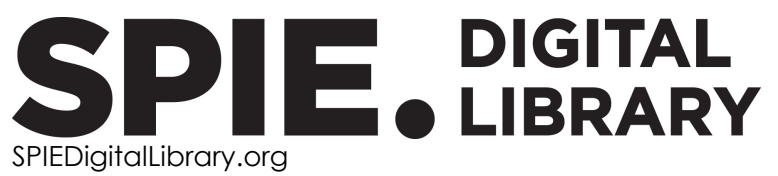

Paper Numbering: Proceedings of SPIE follow an e-First publication model. A unique citation identifier (CID) number is assigned to each article at the time of publication. Utilization of CIDs allows articles to be fully citable as soon as they are published online, and connects the same identifier to all online and print versions of the publication. SPIE uses a seven-digit CID article numbering system structured as follows:

- The first five digits correspond to the SPIE volume number.

- The last two digits indicate publication order within the volume using a Base 36 numbering system employing both numerals and letters. These two-number sets start with $00,01,02,03,04$, 05, 06, 07, 08, 09, OA, OB ... 0Z, followed by 10-1Z, 20-2Z, etc. The CID Number appears on each page of the manuscript. 


\section{Contents}

TURBULENCE MITIGATION

1154303 Analysis of deep learning architectures for turbulence mitigation in long-range imagery (Invited Paper) [11543-1]

1154304 Fast algorithms for model-based imaging through furbulence [11543-2]

\section{MARITIME APPLICATIONS}

1154305 A comprehensive analysis of modern object detection methods for maritime vessel detection (Invited Paper) [1 1543-3]

1154306 CNN-based object detection and segmentation for maritime domain awareness [11543-4]

$1154307 \quad$ Faster-RCNN with a compact CNN backbone for target detection in infrared images [1 1543-5]

1154308 Analysis of different tracking algorithms applied on thermal infrared imagery for maritime surveillance systems [11543-6]

1154309 Deep learning for automatic target recognition with real and synthetic infrared maritime imagery [11543-7]

11543 OA Development of a method for automatic generation and optimization of fuzzy controller parameters using genetic algorithm [11543-23]

$11543 \mathrm{OB} \quad$ Long-range person and vehicle detection [11543-24]

\section{NAVIGATION}

11543 OD Vision communication and vision navigation method for UAV bionic flight [11543-9]

11543 OF Adversarial patch camouflage against aerial detection (Invited Paper) [11543-11]

$115430 \mathrm{OG}$ Investigating robustness of adversarial camouflage (AC) for naval vessels [11543-12] 
11543 ol A multitask model for person re-identification and attribute recognition using semantic regions [11543-14]

$115430 \mathrm{~J} \quad$ Optimal control under communication constraints for multi-agent unmanned vehicles [11543-15]

$11543 \mathrm{OL} \quad$ Heterogeneous neuromorphic processor based on RISC-V architecture for real-time robotics tasks [11543-17]

$11543 \mathrm{OM}$ Unsupervised behaviour anomaly detection from fixed camera full motion video [11543-22]

POSTER SESSION

$1154300 \quad$ Image domain adaption of simulated data for human pose estimation [11543-19]

$11543 \mathrm{OP} \quad$ A deep learning approach to crack detection on road surfaces [11543-20]

11543 OR Very large multimodal multi-architecture convolutional neural network with bundled transfer learning for automated coronavirus diagnosis [11543-25]

11543 OS Interpretable deep learning-based risk evaluation approach [11543-27] 